ARTICLE

\title{
Climate pacing of millennial sea-level change variability in the central and western Mediterranean
}

\author{
Matteo Vacchi (10 ${ }^{1,2 凶}$, Kristen M. Joyse ${ }^{3}$, Robert E. Kopp (i) ${ }^{3}$, Nick Marriner (iD ${ }^{4}$, David Kaniewski ${ }^{5}$ \& \\ Alessio Rovere ${ }^{6}$
}

Future warming in the Mediterranean is expected to significantly exceed global values with unpredictable implications on the sea-level rise rates in the coming decades. Here, we apply an empirical-Bayesian spatio-temporal statistical model to a dataset of 401 sea-level index points from the central and western Mediterranean and reconstruct rates of sea-level change for the past 10,000 years. We demonstrate that the mean rates of Mediterranean industrialera sea-level rise have been significantly faster than any other period since $\sim 4000$ years ago. We further highlight a previously unrecognized variability in Mediterranean sea-level change rates. In the Common Era, this variability correlates with the occurrence of major regionalscale cooling/warming episodes. Our data show a sea-level stabilization during the Late Antique Little Ice Age cold event, which interrupted a general rising trend of $\sim 0.45 \mathrm{~mm} \mathrm{a}^{-1}$ that characterized the warming episodes of the Common Era. By contrast, the Little Ice Age cold event had only minor regional effects on Mediterranean sea-level change rates.

\footnotetext{
${ }^{1}$ Dipartimento di Scienze Della Terra, Università di Pisa, Pisa, Italy. ${ }^{2}$ CIRSEC - Centro Interdipartimentale di Ricerca per lo Studio degli Effetti del Cambiamento climatico dell'Università di Pisa, Pisa, Italy. ${ }^{3}$ Department of Earth \& Planetary Sciences and Rutgers Institute of Earth, Ocean, and Atmospheric Sciences, Rutgers University, New Brunswick, NJ, USA. ${ }^{4}$ CNRS, ThéMA, Université de Franche-Comté, UMR 6049, MSHE Ledoux, Besançon, Cedex, France. ${ }^{5}$ TRACES, UMR 5608 CNRS, Université Toulouse Jean Jaurès, Maison de la Recherche, Toulouse, Cedex 9, France. ${ }^{6}$ MARUM, Center for Marine Environmental Sciences, University of Bremen, Bremen, Germany.凶email: matteo.vacchi@unipi.it
} 
C limate and sea-level reconstructions for the pre-industrial period (i.e., before $1850 \mathrm{CE}$ ) provide context for current and future changes ${ }^{1-3}$. Determining the rates, mechanisms, and geographic variability of relative sea-level (RSL) change following the Last Glacial Maximum (LGM) is relevant to gauging how climatic forcing may influence the rates of future sealevel change ${ }^{3,4}$. Compilations of sea-level proxies have facilitated the quantification of the response of the solid Earth and geoid to ice-mass redistribution ${ }^{5-7}$ and provided constraints for statistical and geophysical models used to project future sea-level rise ${ }^{8}$. The Mediterranean Sea is a semi-enclosed basin lying in a transition zone between mid-latitude and subtropical atmospheric circulation regimes and is characterized by strong land-sea contrasts? For this reason, it is considered a hotspot of current climate change $^{9-11}$, and future warming in the Mediterranean area is expected to exceed global rates by $\sim 25 \%{ }^{12}$. This may result in high sea-level rise rates compared to global averages, leading to significant losses in the environmental, cultural and economic values of Mediterranean coasts ${ }^{13}$. Furthermore, semi-closed basins are poorly resolved by the $\sim 1^{\circ}$ resolution typical of global climate models included in CMIP5/6, which are generally used to drive projections of local dynamic sea-level change ${ }^{14}$. Finally, offset between data and glacio-isostatic adjustment (GIA) models were recently highlighted by extended sea-level records ${ }^{15}$. This adds complexity to defining the magnitude and spatial variability of the isostatic component, which affects both current and future sea-level changes.

The increasing availability of continuous and high-resolution Holocene and Common Era Mediterranean relative sea-level (RSL) reconstructions ${ }^{15,16}$ provides the opportunity to explore the role of climatic factors in mediating sea-level variability in the Holocene (i.e., the last $11.7 \mathrm{ka}$ ). These data are of major importance because regional climatic forcing can lead to significant departures from global mean sea-level projections ${ }^{10}$.

Here, we applied an empirical-Bayesian spatio-temporal statistical model ${ }^{17}$ (see "Methods") to a dataset of 401 sea-level index points (SLIPs), defining the discrete position of past RSL in space and time ${ }^{18}$. We focus our analysis on the central and western Mediterranean (Fig. 1), which are less affected by neotectonic processes $^{19}$ than the eastern part. The results of our analysis constitute the first basin-scale assessment of sea-level variability in the Mediterranean for the last 10,000 years and represent the natural and geological backgrounds against which modern Mediterranean sea-level rise should be quantified.

\section{Results and discussion}

Millennial variability of sea-level change rates. The SLIPs database (Supplementary Table 1) is composed of (i) 391 radiocarbon-dated geological samples from transitional brackish environments, fossil intertidal bioconstructions, beachrocks, and (ii) 12 archeologically dated marine structures whose relationship with the contemporary mean sea-level is robustly defined ${ }^{20}$. The spatial distribution of the SLIPs covers a large portion of the central and northern sectors of the central and western Mediterranean basin, while in the southern sector the available data are restricted to the coasts of Malta and the Gulf of Gabes (Fig. 1). The SLIPs database allowed us to reconstruct the rates of RSL change in 48 sub-regions clustered according to their geographic proximity (Supplementary Fig. 1a). The average vertical accuracy of the different SLIPs is $\pm 0.7 \mathrm{~m}(\max \pm 1.3 \mathrm{~m}$, $\min \pm 0.2 \mathrm{~m})$ while the average age error is $\pm 0.15 \mathrm{ka}(\max 0.62 \mathrm{ka}$, $\min 0.025 \mathrm{ka})$. All errors are reported at $\pm 1 \sigma$. The age of the SLIPs spans the whole Holocene period (Supplementary Fig. 1b). 10.3\% of the SLIPs date to the early Holocene ( $-10,000$ to $-6000 \mathrm{CE}), 32.4 \%$ to the mid-Holocene ( -6000 to $-2000 \mathrm{CE}$ ), and $57.3 \%$ to the late Holocene ( -2000 to $1950 \mathrm{CE})$. Virtually uncompressible samples (see "Methods") represent $36.5 \%$ of the entire record, while $39.4 \%$ of the SLIPs dates between -5000 and 1950 CE (Supplementary Fig. 1b).

The spatio-temporal model allowed us to reconstruct sea-level change rates since $-8000 \mathrm{CE}$. There is a paucity of SLIPs for the

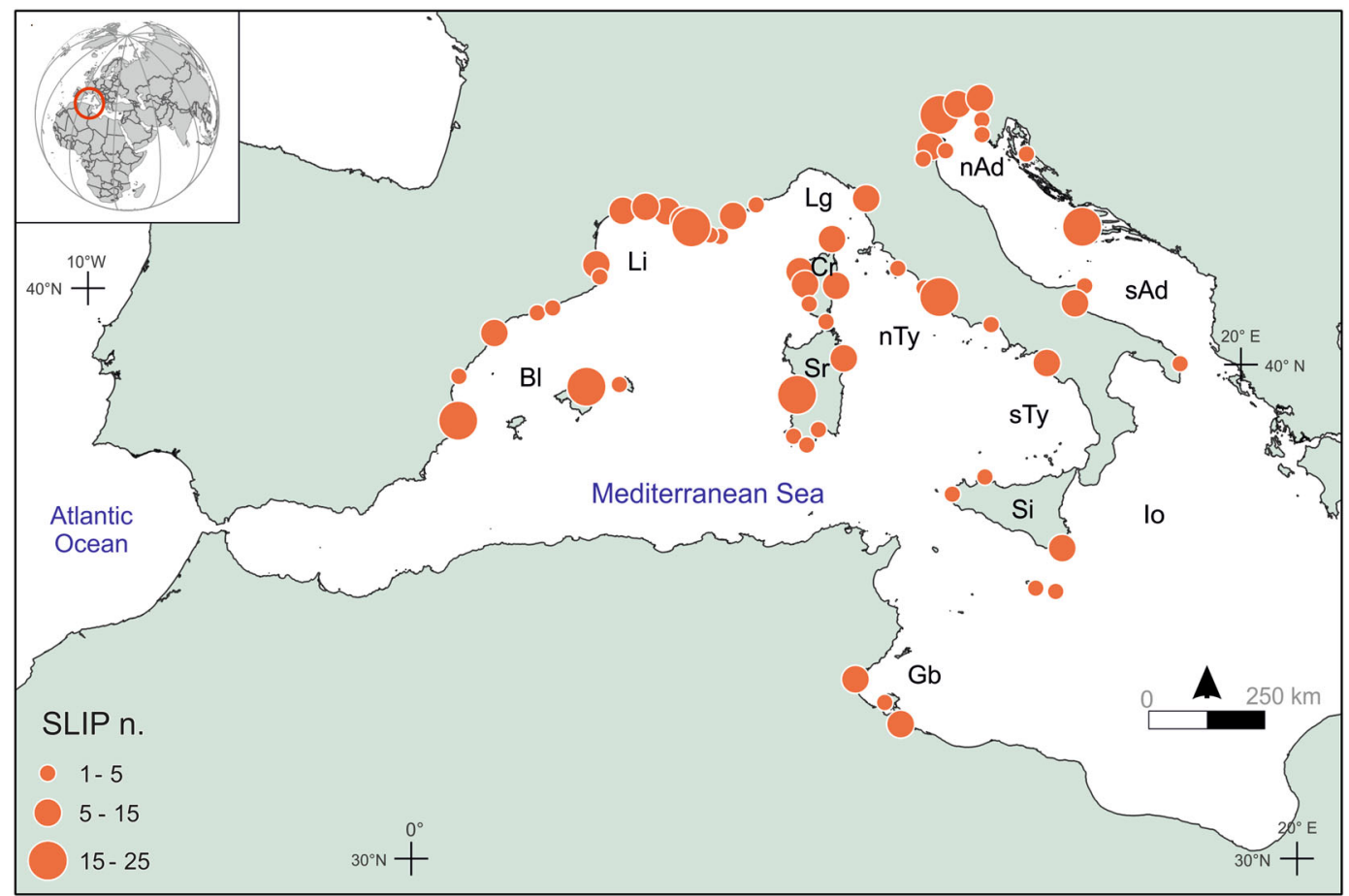

Fig. 1 Spatial distribution of the central and western Mediterranean sea-level index points (SLIPs) used for this analysis. $B r$ is the Balearic Sea; $L i$ is the Gulf of Lion; Lg is the Ligurian Sea; nTy is the northern Tyrrhenian Sea; sTy is the southern Thyrrenian Sea; Gb is the Gulf of Gabes; lo is the lonian Sea; nAd is the northern Adriatic; sAd is the southern Adriatic Sea; Sr is Sardinia Island; $\mathrm{Cr}$ is Corsica Island; Si is Sicily Island. 
period $-10,000$ to $-8000 \mathrm{CE}$. From the model, it was possible to calculate the "central and western Mediterranean Sea-Level" (Med-SL), which represents the common signal found at all sites included in the model runs (Fig. 2a and Supplementary Table 2). The Med-SL, which is uniform over the entire central and western Mediterranean, absorbs a majority of the sea-level signal, whereas the regional signals (Fig. 2b, Supplementary Fig. 2) explain the variability we can observe at the basin scale. The model also estimates RSL for locations and times where there are no direct observations because it recognizes that an observation associated with a single point in space and time is informative about sea-level at proximal locations and times.

Med-SL estimates (Fig. 2a) indicate that the central and western Mediterranean sea-level rise decreased from $8.7 \pm 0.9 \mathrm{~mm} \mathrm{a}^{-1}$ to $3.1 \pm 0.8 \mathrm{~mm} \mathrm{a}^{-1}$ during the period -8000 to $-5000 \mathrm{CE}$. The slowdown continued over subsequent millennia, with average rates of $1.5 \pm 0.8 \mathrm{~mm} \mathrm{a}^{-1}$ between -5000 and $-2000 \mathrm{CE}, 0.5 \pm$ $0.7 \mathrm{~mm} \mathrm{a}^{-1}$ between -2000 and $0 \mathrm{CE}$, and $0.45 \pm 0.7 \mathrm{~mm} \mathrm{a}^{-1}$ in the last 2000 years. This stabilization trend reflects the general decrease in rates of global sea-level change consistent with the final phase of North American deglaciation and the consequent sudden reduction of meltwater input and with the stabilization of global mean surface temperature ${ }^{7,21}$. Between -2000 and 1850 $\mathrm{CE}$, the ice-equivalent meltwater input is either zero or minimal $^{21,22}$. During this period, Med-SL rise rates ranged between $0.30 \pm 0.7 \mathrm{~mm} \mathrm{a}^{-1}$ and $0.55 \pm 0.6 \mathrm{~mm} \mathrm{a}^{-1}$, while in the industrial-era (e.g., post $1850 \mathrm{CE}$ ) rates increased up to $1.05 \pm$ $0.6 \mathrm{~mm} \mathrm{a}^{-1}$ (Fig. 2a, Supplementary Table 2). This acceleration closely mirrors post-industrial warming observed in several

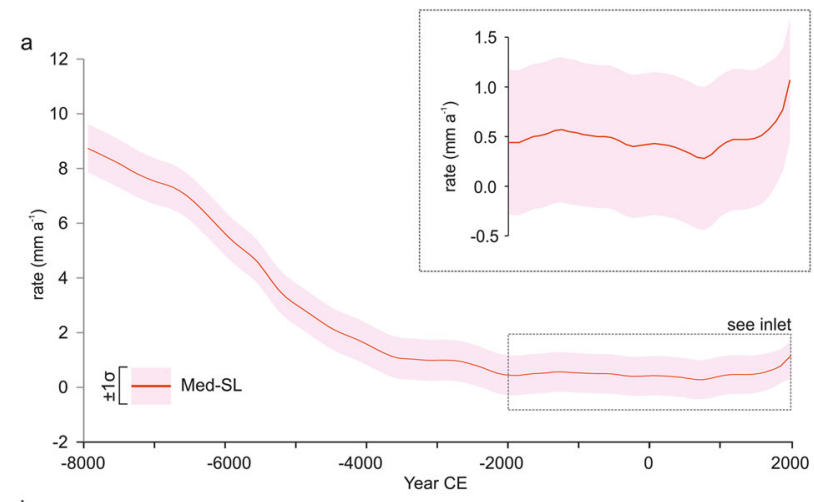

b

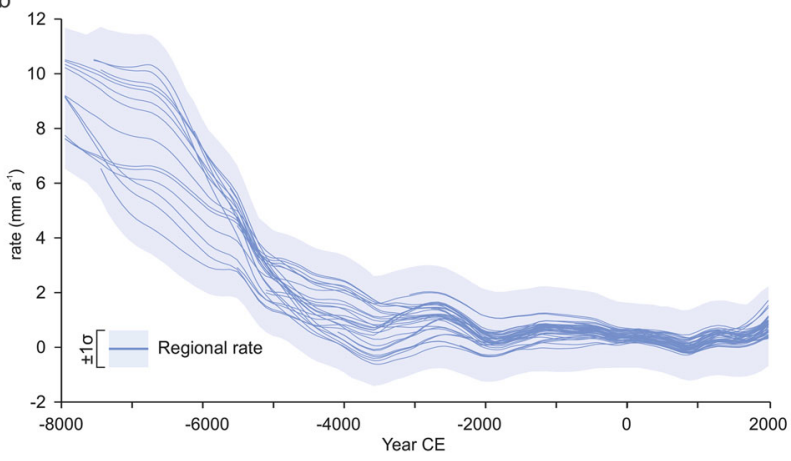

Fig. 2 Rates of relative sea-level change for the central and western Mediterranean region in the last $\mathbf{1 0 , 0 0 0}$ years. a Common sea-level signal (Med-SL). The inlet graph shows the Med-SL variation in the last 4000 years. The solid line and shaded envelope denote the model mean and the $1 \sigma$ uncertainty (see Supplementary Table 2 ). b variability of relative sea-level (RSL) change rates in the 48 central and western Mediterranean regions included in the analysis. The solid line and shaded envelope are the model mean and $1 \mathrm{~s}$ uncertainty.
Mediterranean climatic proxies ${ }^{12}$ and is consistent with the data extracted from the longest central and western Mediterranean tide-gauge data, which indicate sea-level rise rates of about $1.2-1.3 \mathrm{~mm} \mathrm{a}^{-123,24}$ for the period 1880-2012 CE. Even higher rates $\left(1.7-1.8 \mathrm{~mm} \mathrm{a}^{-1}\right)$ are observed for the second part of the last century, indicated by a larger dataset of tidal gauges and satellite altimetry ${ }^{25,26}$. This indicates that, at the basin scale, the mean estimate of industrial-era sea-level rising rate has no equivalent analog during the last 4000 years and that the rate of central and western Mediterranean industrial-era sea-level rise is unlikely ( $25 \%$ probability) to be a random occurrence (Supplementary Fig. 3).

Our analysis highlights significant variability in the regional rates of sea-level change (Fig. 2b, Supplementary Fig. 2), which resulted in contrasting sea-level rising trends in the different portions of the Mediterranean basin analyzed in this study. Between -8000 and $-5000 \mathrm{CE}$, faster sea-level rise rates were observed in the mid-western portion of the basin $\left(<\sim 10^{\circ} \mathrm{E}\right)$ with rates of $8.0 \pm 0.4 \mathrm{~mm} \mathrm{a}^{-1}$ (Fig. 3). During the same period, sealevel rose much slower in the eastern portion of the basin $\left(>\sim 10^{\circ}\right.$ E) with rates that did not exceed $5.0 \pm 0.5 \mathrm{~mm} \mathrm{a}^{-1}$ (Fig. 3). We then observed an inversion in this rising pattern after sea-level stabilized around $-5000 \mathrm{CE}$. Since that period, rates of sea-level rise were always slower in the western portion of the basin $\left(<\sim 5^{\circ}\right.$ E) compared to the mid-eastern part $\left(>\sim 5^{\circ} \mathrm{E}\right.$, Fig. 3). These differences are particularly significant between -5000 and -2000 $\mathrm{CE}$ when low average rise rates $\left(0.5 \pm 0.2 \mathrm{~mm} \mathrm{a}^{-1}\right)$ are recorded in the Balearic Sea while high average rates $\left(2.0 \pm 0.3 \mathrm{~mm} \mathrm{a}^{-1}\right)$ characterize the Ionian Sea. In the last 4000 years, we observed a progressive decrease in the spatial variability of the rising with maximum average rates $\left(0.8 \pm 0.2 \mathrm{~mm} \mathrm{a}^{-1}\right)$ still recorded in the Ionian Sea, while minimal average rates $\left(0.2 \pm 0.2 \mathrm{~mm} \mathrm{a}^{-1}\right)$ are recorded both in the Balearic Sea and in the Gulf of Gabes (Fig. 3). We remark that the Gulf of Gabes, in Tunisia, represents a unique setting within the Mediterranean, as it is the only Mediterranean region where a purely isostatic mid-Holocene highstand is recorded, mediated by continental levering effects ${ }^{27}$.

Sediment compaction and tectonics may have a role in controlling the observed spatial variability of sea-level change rates among regions. However, these components were minimized in our SLIPs database by prioritizing samples that are virtually incompressible or less prone to compaction, and by excluding data from regions that are significantly affected by coseismic or volcano-tectonic vertical ground motions (see "Methods"). For this reason, much of the observed spatial variability of sea-level change rates is related to glacio- and hydroisostatic adjustment (GIA), which has been the dominant process influencing the Mediterranean RSL evolution since the global mean sea-level stabilization of the mid-Holocene $e^{7,23}$. Our data indicate a general eastward increase of the GIA component in the central and western Mediterranean basin with minimal isostaticdriven subsidence recorded along the Spanish coast and in the Balearic Islands and maximum rates recorded in the Ionian Sea. This pattern differs from the one proposed by the available GIA models ${ }^{7,28}$ which predict the maximal GIA-related sea-level change, with comparable magnitude, in the Ionian Sea and in the area comprising the Balearic, Sardinia and Corsica islands (Supplementary Fig. 3). The offset between the data and models is probably related to lateral variations in mantle viscosity and/or in the thickness of the lithosphere, which are currently not taken into account by Mediterranean GIA models ${ }^{15,29}$. Lateral heterogeneity of the Earth's mantle may significantly affect the Earth's response to deglaciation ${ }^{30,31}$. Our results can thus be employed for an improved tuning of geophysical predictions of RSL evolution in the basin, which is characterized by significant variability in lithospheric thickness and complex mantle 

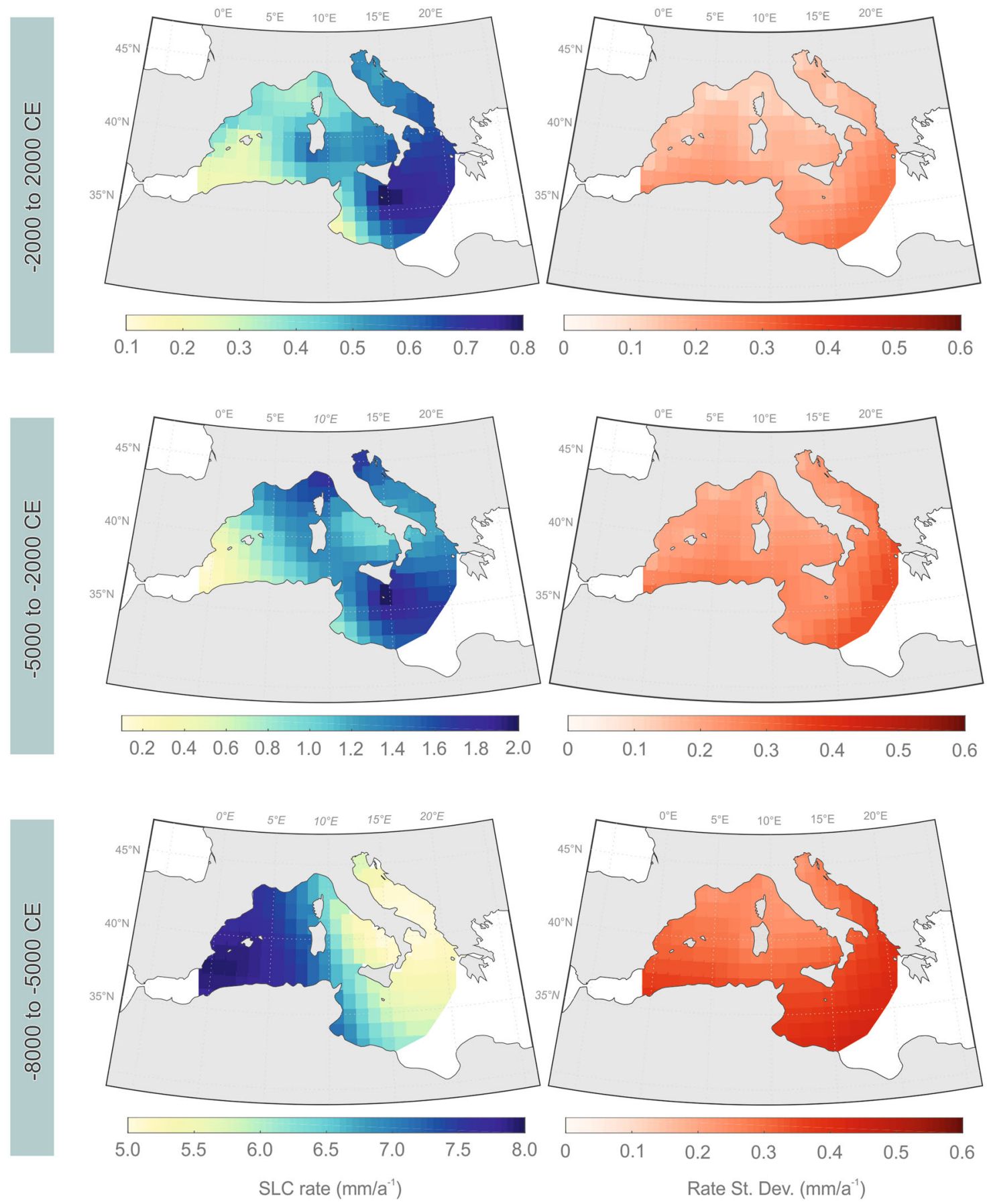

Fig. 3 Spatial and temporal variability of relative sea-level (RSL) changes and their uncertainties across the central and western Mediterranean basin in the time periods 2000 to -2000 CE, -2000 to $-\mathbf{5 0 0 0}$ CE, and $-\mathbf{5 0 0 0}$ to $-\mathbf{8 0 0 0}$ CE. Note the changes of scale for the different time intervals.

structure $^{19}$. Nonetheless, it should be noted that our analysis has some geographic limitations due to the absence of SLIPs along much of the African coast and near the Gibraltar Strait.

Regional climatic influence on sea-level rise rates. Notwithstanding regional differences, our spatio-temporal analysis shows that the central and western Mediterranean regions were characterized by several sea-level oscillations in the last 6 millennia (Supplementary Fig. 2). Looking for the source of these sea-level oscillations, isostatic processes can be excluded. Isostasy is, by definition, a progressive and slow viscoelastic response of the Earth to the redistribution of ice and ocean loads ${ }^{32,33}$. GIA modeling is unable to resolve the scale of sea-level fluctuations observed, and the oscillatory patterns observed have a period that is too short to be influenced by glacio-isostatic processes. The fact that these fluctuations were observed across all regions would also exclude potential local tectonic influences and compactionrelated subsidence. Instead, we suggest that regional climatic forcings are the most likely mechanism driving the variability in the sea-level change data.

In effect, while it is known that large ice melting was minimal after $-2000 \mathrm{CE}^{21,34}$, much less is known about the responses to shorter-term Mediterranean climatic changes ${ }^{35,36}$ such as the Roman Warm Period (RWP, -500 CE to 500 CE), the Late Antique Little Ice Age (LALIA, $\sim 536$ to $\sim 660 \mathrm{CE}$ ), the Medieval Climate Anomaly (MCA, $\sim 860$ to $\sim 1250 \mathrm{CE}$ ) and the Little Ice 
Age (LIA, $\sim 1250$ to $\sim 1850 \mathrm{CE}$ ). In the Common Era, Med-SL rise rates varied within a range of $\sim 0.9 \mathrm{~mm} \mathrm{a}^{-1}$ (Supplementary Table 2, Fig. 4). Rise rates up to $0.5 \pm 0.7 \mathrm{~mm} \mathrm{a}^{-1}$ characterized the warmer episode occurring at the RWP while we observed a deceleration of the sea-level change rates $\left(0.3 \pm 0.7 \mathrm{~mm} \mathrm{a}^{-1}\right)$ during the LALIA (Fig. 4). The LALIA is recognized as one of the most important cooling episodes of the Common $\mathrm{Era}^{36}$. This cooling event is found in different proxies (Fig. 4) such as temperature anomalies in Europe $\mathrm{e}^{37}$, and specifically in the central and western Mediterranean ${ }^{38,39}$ and the European Alps $^{36}$. During this period, we also observe a decrease in sea-surface temperatures (SSTs) in the western Mediterranean ${ }^{40}$, as well as the exceptional seventh-century solar minimum ${ }^{41}$.
The rising trend only returned to values similar to the preLALIA $\left(0.45 \pm 0.7 \mathrm{~mm} \mathrm{a}^{-1}\right)$ during the MCA which was characterized by warmer climatic conditions (Fig. 4) and remained at similar values for much of the LIA (1250-1600 CE) suggesting a negligible influence of this cooling episode on central and western Mediterranean sea-level rise rates. In the remaining part of the pre-industrial period (1600 and $1800 \mathrm{CE}$ ) rates rose to $0.6 \pm 0.6$ $\mathrm{mm} \mathrm{a}^{-1}$ while we observed a progressive acceleration of sea-level rise in the industrial-era, with rates up to $1.05 \pm 0.6 \mathrm{~mm} \mathrm{a}^{-1}$ (Fig. 4), which are significantly faster than any warm climatic episode of the Common Era.

Our spatio-temporal analysis shows a strong relationship between Mediterranean temperatures and the rate of sea-level rise

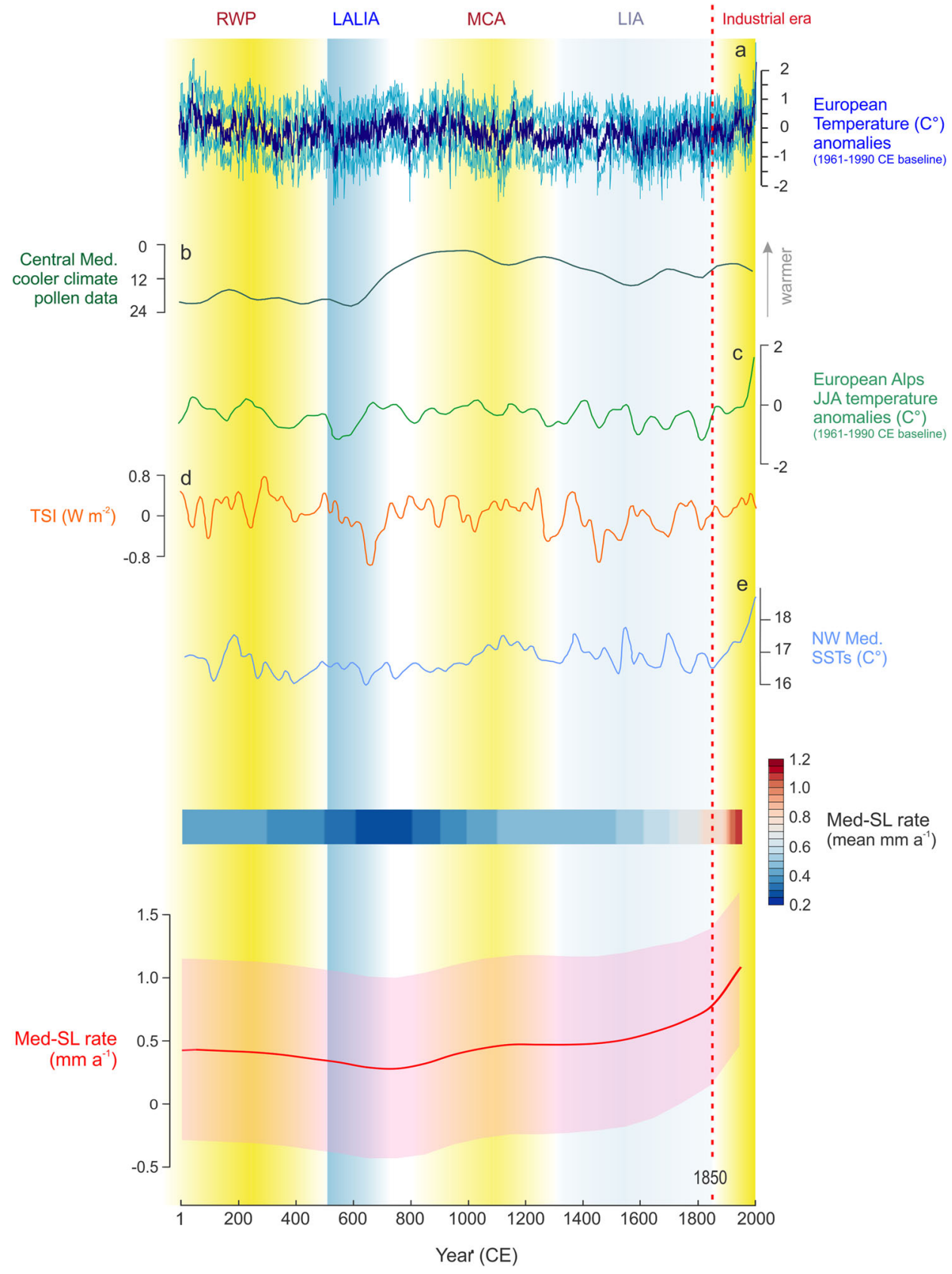

Fig. 4 Reconstructed variability of common sea-level signal (Med-SL) for the central and western Mediterranean region in the Common Era. Solid line and shaded envelope are the model mean and $1 \mathrm{~s}$ uncertainty. Med-SL is compared with a European Temperature anomalies ${ }^{37}$, $\mathbf{b}$ central Mediterranean cooler climate pollen data ${ }^{38}, \mathbf{c}$ summer (JJ) temperature anomalies in the European Alps ${ }^{36}, \mathbf{d}$ total solar irradiance ${ }^{41}$, e sea-surface temperatures (SSTs) in the western Mediterranean ${ }^{40}$. Temporal extension of the Roman Warm Period (RWP), the Late Antique Little Ice Age (LALIA), the Medieval Climate Anomaly (MCA), the Little Ice Age (LIA), and the Industrial period are from refs. ${ }^{35,36}$. The graded bar is the Med-SL model mean. 
confirming, at the basin scale, the results locally obtained in the northwestern Adriatic Sea ${ }^{42}$. These oscillations are thus controlled by the differential response of Mediterranean sea-level to cooling/warming episodes, as demonstrated by the variability of sea-level rise rates observed in the Common Era.

Therefore, our findings suggest that a deeper exploration of the regional climatic parameters, controlling the variability of rise rates, is required to produce robust predictions of Mediterranean sea-level evolution in a changing climate. Regionally, global predictions of sea-level rise may be worsened by the expected increased warming of the Mediterranean ${ }^{9}$. This may have major implications for the near-future resilience of both natural and human-modified Mediterranean coasts, characterized by a narrow littoral area with high concentrations of people and assets and by rapid demographic, social, economic, and environmental change ${ }^{43,44}$.

\section{Methods}

SLIPs database. We collated a database of SLIPs following the most recent standards in sea-level studies ${ }^{18,45}$. The analysis of a wide range of geological and archeological proxies ${ }^{46-133}$ resulted in a database of 401 SLIPs (Supplementary Table 1) that identify the position of former RSL in the central and western Mediterranean coasts from $12 \mathrm{ka}$ to present (Supplementary Fig. 1b). Mediterranean SLIPs are commonly derived from cores on coastal and alluvial plains, coastal marshes, and lagoons. For these samples, the definition of the indicative meaning is based on paleoecology and, in particular, on the macro-and micro-faunal assemblages (i.e., malacofauna, foraminifera, and ostracod assemblages). Furthermore, fossil intertidal bioconstructions (e.g., vermetids and Lithophyllum byssoides rims) and beachrocks have also yielded SLIPs for the Mediterranean region ${ }^{15,16}$. Finally, we produced SLIPs using maritime archeological structures whose functioning height is related to the former mean sea level such as fishtanks ${ }^{20}$ or when found covered by fossil biological encrustations which clearly define the relationship with the former tidal frame ${ }^{134}$. We did not include samples from sectors manifesting major evidence for co-seismic land-level changes and/or crustal movements controlled by volcanic activity ${ }^{135,136}$, which can generate significant departures from climatic-driven sea-level changes. Sediment compaction can be an important issue because it can lower the SLIP relative to the initial depositional elevation, resulting in an overestimation of the sea-level rise ${ }^{18,137}$. In the database compilation, we prioritized "base of basal" samples, e.g., those recovered from sedimentary units overlying incompressible substrates such as Pleistocene sands/gravels or rocky basements. These samples are, therefore, less prone to compaction ${ }^{6}$. Where basal samples were not available, we used intercalated samples which are derived from facies of low-density, organic-rich sediment within a sequence of higher density, clastic units ${ }^{18,137}$, and are, therefore, susceptible to compaction. However, in the presence of two or more coeval intercalated SLIPs in the same region, we excluded those found at lower elevation as being affected by post-depositional compaction ${ }^{137}$. This procedure was of particular importance for the Rhone, Ebro, and Tiber deltas, for Venice lagoon, and for the Romagna and Versilia coastal plains. This practice allowed us to significantly reduce the effects of compaction on the SLIPs dataset. The fossil intertidal bioconstructions, beachrocks, and archeological structures are not subject to compaction. To perform a high-resolution assessment of variability in sea-level rise rates we clustered the data into $48 \mathrm{sub}$ regions, based on SLIPs collected no more than $\sim 50 \mathrm{~km}$ apart (Supplementary Fig. 1a).

Spatio-temporal statistical model. We employed an empirical spatio-temporal hierarchical model ${ }^{16}$ to reconstruct the common sea-level change across the central and western Mediterranean Basin, sub-regional variability in RSL changes, and spatial-temporal variability patterns in rates of RSL change across the basin over the last $10 \mathrm{ka}$. The height and timing (with vertical and temporal errors) of paleoRSL from the 401 SLIPs from 48 sub-regions in the central and western Mediterranean database were fed into the model. Additional model inputs came from tide-gauge records taken from the Permanent Service for Mean Sea Level (PSMSL) (see Kopp et al. ${ }^{3}$ for more details). Spatio-temporal variabilities of RSL change and their uncertainties (Fig. 3) are calculated through a linear transformation of the RSL predictions.

The hierarchical model has three levels: (i) a process level, which models RSL through space and time; (ii) a data level, which models how RSL from the process model is recorded by geological proxies; and (iii) a hyperparameter level, which describes the prior expectations for spatial and temporal RSL variability.

The process model represents the RSL field as the sum of three components, each with a Gaussian Process (GP) prior:

$$
f(x, t)=g_{b}(t)+r_{s}(x, t)+r_{f}(x, t)
$$

where $\boldsymbol{x}$ represents a spatial location and $\boldsymbol{t}$ represents time. The three components that comprise the RSL field are $g_{b}$, which is the common Med-SL signal; $r_{s}(x, t)$, which represents the sub-regionally varying, slow, and temporally non-linear SL field; and $r_{f}(x, t)$, which represents the sub-regionally varying, fast and temporally non-linear SL field. As in Kopp et al. ${ }^{3}$, the data model represents observations $\left(\boldsymbol{y}_{\boldsymbol{i}}\right)$ as:

$$
y_{i}=f\left(x_{i}, t_{i}\right)+w\left(x_{i}, t_{i}\right)+y_{0}\left(x_{i}\right)+\varepsilon_{i}^{y}
$$

where $x_{i}$ and $t_{i}$ are the location and time, respectively, of observation $i, w(x, t)$ is a white noise term that captures sub-decadal changes in RSL and vertical errors beyond those nominally represented in the database, and $y_{o}\left(x_{i}\right)$ is a site-specific datum offset. $\varepsilon_{i}^{y}$ represents errors in sea-level observations, and the term for time $t_{i}$ is the sum of the mean observed age and an error term for time. As in Kopp et al. ${ }^{3}$, geochronological uncertainties are incorporated using the noisy-input GP method $^{138}$, which translates errors in the independent variable into comparable errors in the dependent variable.

Hyperparameters that define prior knowledge of the amplitude and spatiotemporal scales for sea-level in each term of the process model were optimized via maximum likelihood. Optimized prior standard deviations for the common, slow, fast, and white noise terms were $10.4 \mathrm{~m}, 1.72 \mathrm{~m}, 2 \mathrm{~cm}$, and $7 \mathrm{~mm}$, respectively. The optimized temporal scales for the common, slow, and fast components were 12200 3590 , and 14.1 years, respectively, while the optimized spatial scales for the slow and fast components were $14^{\circ}$ and $2^{\circ}$ angular distances, respectively.

\section{Data availability}

Data related to this article can be found in Supplementary Table 1 (SLIP database) and Supplementary Table 2 (Med-SL rates). The references of the original papers used to produce the SLIP database are provided at the end of Supplementary Table 1. These data are available under a CC-BY 4.0 license at the following https://doi.org/10.5281/ zenodo.4737120.

\section{Code availability}

The code used for analysis in this article is archived on GitHub (https://github.com/ bobkopp/CESL-STEHM-GP).

Received: 18 January 2021; Accepted: 26 May 2021; Published online: 29 June 2021

\section{References}

1. Church, J. A. \& White, N. J. A 20th century acceleration in global sea-level rise. Geophys. Res. Lett. 33, https://doi.org/10.1029/2005GL024826 (2006).

2. Kemp, A. C. et al. Climate related sea-level variations over the past two millennia. Proc. Natl Acad. Sci. USA 108, 11017-11022 (2011).

3. Kopp, R. E. et al. Temperature-driven global sea-level variability in the Common Era. Proc. Natl Acad. Sci. USA 113, E1434-E1441 (2016).

4. Kench, P. S. et al. Climate-forced sea-level lowstands in the Indian Ocean during the last two millennia. Nat. Geosci. 13, 61-64 (2020).

5. Mitrovica, J. X. et al. On the robustness of predictions of sea level fingerprints. Geophys. J. Int. 187, 729-742 (2011)

6. García-Artola, A. et al. Holocene sea-level database from the Atlantic coast of Europe. Quat. Sci. Rev. 196, 177-192 (2018).

7. Roy, K. \& Peltier, W. R. Relative sea level in the Western Mediterranean basin a regional test of the ICE-7G_NA (VM7) model and a constraint on late Holocene Antarctic deglaciation. Quat. Sci. Rev. 183, 76-87 (2018).

8. Horton, B. P. et al. Mapping sea-level change in time, space, and probability. Annu. Rev. Environ. Resour. 43, 481-521 (2018).

9. Cramer, W. et al. Climate change and interconnected risks to sustainable development in the Mediterranean. Nat. Clim. Change 8, 972-980 (2018).

10. Adloff, F. et al. Mediterranean Sea response to climate change in an ensemble of twenty first century scenarios. Clim. Dyn. 45, 2775-2802 (2015).

11. Guiot, J. \& Cramer, W. Climate change: the 2015 Paris Agreement thresholds and Mediterranean basin ecosystems. Science 354, 465-468 (2016).

12. Lionello, P. \& Scarascia, L. The relation between climate change in the Mediterranean region and global warming. Regional Environ. Change 18, 1481-1493 (2018).

13. Anzidei, M. et al. Sea level rise scenario for $2100 \mathrm{AD}$ in the heritage site of Pyrgi (Santa Severa, Italy). J. Mar. Sci. Eng. 8, 64 (2020).

14. Eyring, V. et al. Overview of the Coupled Model Intercomparison Project Phase 6 (CMIP6) experimental design and organization. Geoscientific Model Dev. 9, 1937-1958 (2016).

15. Vacchi, M. et al. New relative sea-level insights into the isostatic history of the Western Mediterranean. Quat. Sci. Rev. 201, 396-408 (2018).

16. Vacchi, M. et al. Multiproxy assessment of Holocene relative sea-level changes in the western Mediterranean: sea-level variability and improvements in the definition of the isostatic signal. Earth-Sci. Rev. 155, 172-197 (2016).

17. Ashe, E. L. et al. Statistical modeling of rates and trends in Holocene relative sea level. Quat. Sci. Rev. 204, 58-77 (2019). 
18. Shennan, I., Long, A. J. \& Horton, B. P. Handbook of Sea-level Research Ch. 1 (John Wiley \& Sons, 2015).

19. Faccenna, C. et al. Mantle dynamics in the Mediterranean. Rev. Geophysics 52, 283-332 (2014).

20. Benjamin, J. et al. Late Quaternary sea-level changes and early human societies in the central and eastern Mediterranean Basin: an interdisciplinary review. Quat. Int. 449, 29-57 (2017).

21. Peltier, W. R. Global glacial isostasy and the surface of the ice-age Earth: the ICE-5G (VM2) model and GRACE. Annu. Rev. Earth Planet. Sci. 32, 111-149 (2004).

22. Milne, G. A., Long, A. J. \& Bassett, S. E. Modelling Holocene relative sea-level observations from the Caribbean and South America. Quat. Sci. Rev. 24, 1183-1202 (2005).

23. Marcos, M. \& Tsimplis, M. N. Coastal sea level trends in Southern Europe. Geophys. J. Int. 175, 70-82 (2008).

24. Zerbini, S. et al. Sea-level change in the Northern Mediterranean Sea from long-period tide gauge time series. Earth-Sci. Rev. 167, 72-87 (2017).

25. Wöppelmann, G. \& Marcos, M. Coastal sea level rise in southern Europe and the nonclimate contribution of vertical land motion. J. Geophys. Res. Oceans 117, https://doi.org/10.1029/2011JC007469 (2012).

26. Anzidei, M. et al. Coastal structure, sea-level changes and vertical motion of the land in the Mediterranean. Geolog. Soc. Lond., Spec. Publ. 388, 453-479 (2014).

27. Stocchi, P., Colleoni, F. \& Spada, G. Bounds on the time-history and Holocene mass budget of Antarctica from sea-level records in SE Tunisia. Pure Appl. Geophysics 166, 1319-1341 (2009).

28. Lambeck, K. \& Purcell, A. Sea-level change in the Mediterranean Sea since the LGM: model predictions for tectonically stable areas. Quat. Sci. Rev. 24, 1969-1988 (2005).

29. Stocchi, P. et al. MIS 5e relative sea-level changes in the Mediterranean Sea: contribution of isostatic disequilibrium. Quat. Sci. Rev. 185, 122-134 (2018).

30. Spada, G., Antonioli, A., Cianetti, S. \& Giunchi, C. Glacial isostatic adjustment and relative sea-level changes: the role of lithospheric and upper mantle heterogeneities in a 3-D spherical Earth. Geophys. J. Int. 165, 692-702 (2006).

31. Kuchar, J., Milne, G. \& Latychev, K. The importance of lateral Earth structure for North American glacial isostatic adjustment. Earth Planet. Sci. Lett. 512, 236-245 (2019).

32. Milne, G. A. \& Mitrovica, J. X. Postglacial sea-level change on a rotating Earth. Geophys. J. Int. 133, 1-19 (1998).

33. Melini, D. \& Spada, G. Some remarks on Glacial Isostatic Adjustment modelling uncertainties. Geophys. J. Int. 218, 401-413 (2019).

34. Lambeck, K., Rouby, H., Purcell, A., Sun, Y. \& Sambridge, M. Sea level and global ice volumes from the Last Glacial Maximum to the Holocene. Proc. Natl Acad. Sci. USA 111, 15296-15303 (2014).

35. Margaritelli, G. et al. Marine response to climate changes during the last five millennia in the central Mediterranean Sea. Glob. Planet. Change 142, 53-72 (2016).

36. Büntgen, U. et al. Cooling and societal change during the Late Antique Little Ice Age from 536 to around 660 AD. Nat. Geosci. 9, 231-236 (2016)

37. Luterbacher, J. et al. European summer temperatures since Roman times. Environ. Res. Lett. 11, 024001 (2016)

38. Kaniewski, D. et al. Solar pacing of storm surges, coastal flooding and agricultural losses in the Central Mediterranean. Sci. Rep. 6, 25197 (2016).

39. Kaniewski, D. et al. Recent anthropogenic climate change exceeds the rate and magnitude of natural Holocene variability on the Balearic Islands. Anthropocene 32, 100268 (2020).

40. Sicre, M. A. et al. Sea surface temperature variability in the North Western Mediterranean Sea (Gulf of Lion) during the Common Era. Earth Planet. Sci. Lett. 456, 124-133 (2016).

41. Steinhilber, F., Beer, J. \& Fröhlich, C. Total solar irradiance during the Holocene. Geophysi. Res. Lett. 36, https://doi.org/10.1029/2009GL040142 (2009).

42. Faivre, S., Bakran-Petricioli, T., Barešić, J., Horvatić, D. \& Macario, K. Relative sea-level change and climate change in the Northeastern Adriatic during the last $1.5 \mathrm{ka}$ (Istria, Croatia). Quat. Sci. Rev. 222, 105909 (2019).

43. Wolff, C. et al. A Mediterranean coastal database for assessing the impacts of sea-level rise and associated hazards. Sci. Data 5, 180044 (2018).

44. Furlan, E. et al. Development of a Multi-Dimensional Coastal Vulnerability Index: assessing vulnerability to inundation scenarios in the Italian coast. Sci. Total Environ. 772, 144650 (2021).

45. Khan, N. S. et al. Inception of a global atlas of sea levels since the Last Glacial Maximum. Quat. Sci. Rev. 220, 359-371 (2019).

46. Ferrer-García, C. \& Blázquez-Morilla, A. M. The evolution of the Albufereta lagoon (western Mediterranean): climate cycles and sea-level changes. J. Coast. Res. 28, 1617-1626 (2012).

47. Brisset, E., Burjachs, F., Navarro, B. J. B. \& de Pablo, J. F. L. Socio-ecological adaptation to Early-Holocene sea-level rise in the western Mediterranean. Glob. Planet. change 169, 156-167 (2018).
48. Dupré, M., Fumanal, M. P., Sanjaume, E., Santisteban, C. \& Usera, J. Quaternary evolution of Pego coastal lagoon (Southern Valencia, Spain). Palaeogeogr. Palaeoclimatol. Palaeoecol. 68, 291-299 (1988).

49. Ruiz, J. M. \& Carmona, P. La llanura deltaica de los ríos Júcar y Turia y la Albufera de Valencia. Geomorfologia $i$ Quat. litoral Homenatge al Dr. V. Rosselló 1, 399-419 (2005).

50. Marco-Barba, J., Holmes, J. A., Mesquita-Joanes, F. \& Miracle, M. R. The influence of climate and sea-level change on the Holocene evolution of a Mediterranean coastal lagoon: evidence from ostracod palaeoecology and geochemistry. Geobios 46, 409-421 (2013).

51. Sanjaume, E., Segura, F., Garcia, M. L. \& Pardo, J. Recent sedimentation in Valencia Lagoon: preliminary results. J. Coast. Res. 8, 688-698 (1992).

52. Carmona, P. \& Ballester, J. P. Geomorphology, geoarchaeology and ancient settlement in the Valencian Gulf (Spain). m.éditerranée. Rev. g.éographique des. pays m.éditerranéens./J. Mediterranean Geogr. 117, 61-72 (2011).

53. Rodríguez-Pérez, A., Blázquez, A. M., Guillem, J. \& Usera, J. Maximum flood area during MIS 1 in the Almenara marshland (western Mediterranean): Benthic foraminifera and sedimentary record. Holocene 28, 1452-1466 (2018)

54. Carmona, P. et al. Environmental evolution and mid-late Holocene climate events in the Valencia lagoon (Mediterranean coast of Spain). Holocene 26, 1750-1765 (2016)

55. Blázquez, A. M., Rodríguez-Pérez, A., Torres, T. \& Ortiz, J. E. Evidence for Holocene sea level and climate change from Almenara marsh (western Mediterranean). Quat. Res. 88, 206-222 (2017).

56. Giaime, M. et al. In search of Pollentia's southern harbour: geoarchaeological evidence from the Bay of Alcúdia (Mallorca, Spain). Palaeogeogr., Palaeoclimatol., Palaeoecol. 466, 184-201 (2017).

57. Yll, R., Pantaleón-Cano, J., Pérez-Obiol, R. P. \& Roure, J. M. Cambio climático y transformación del medio durante el Holoceno en las Islas Baleares. Congrés del Neolític a la Península Ibérica. Saguntum Extra 2, 45-51 (1999).

58. Burjachs, F., Pérez-Obiol, R., Roure, J. M. \& Julià, R. Dinámica de la vegetación durante el Holoceno en la isla de Mallorca. Trabajos de Palinología básica y aplicada 199-210 (1994).

59. Cearreta, A., Benito, X., Ibáñez, C., Trobajo, R. \& Giosan, L. Holocene palaeoenvironmental evolution of the Ebro Delta (Western Mediterranean Sea): evidence for an early construction based on the benthic foraminiferal record. Holocene 26, 1438-1456 (2016).

60. Riera-Mora, S. \& Esteban-Amat, A. Vegetation history and human activity during the last 6000 years on the central Catalan coast (northeastern Iberian Peninsula). Vegetation Hist. Archaeobotany 3, 7-23 (1994).

61. Daura, J. et al. Palaeoenvironmental record of the Cal Maurici wetland sediment archive in Barcelona (NE Iberian Peninsula) between c. 6000 and 4000 cal. yr BP. Holocene 26, 1020-1039 (2016).

62. Ejarque, A. et al. Coastal evolution in a Mediterranean microtidal zone: Mid to Late Holocene natural dynamics and human management of the Castelló lagoon, NE Spain. PLoS ONE 11, e0155446 (2016).

63. Laborel, J. et al. Biological evidence of sea-level rise during the last 4500 year on the rocky coasts of continental southwestern France and Corsica. Mar. Geol. 120, 203-223 (1994).

64. Sabatier, P. et al. Holocene evolution of a Languedocian lagoonal environment controlled by inherited coastal morphology (South of France). Bull. de. la Soc. Geologique de. Fr. 181, 27-36 (2010).

65. Vella, C. \& Provansal, M. Relative sea-level rise and neotectonic events during the last $6500 \mathrm{yr}$ on the southern eastern Rhône delta, France. Mar. Geol. 170 27-39 (2000)

66. Amorosi, A., Rossi, V. \& Vella, C. Stepwise post-glacial transgression in the Rhône Delta area as revealed by high-resolution core data. Palaeogeogr. Palaeoclimatol., Palaeoecol. 374, 314-326 (2013).

67. Morhange, C., Laborel, J. \& Hesnard, A. Changes of relative sea level during the past 5000 years in the ancient habour of Marseilles, Southern France. Palaeogeogr., Palaeoclimatol., Palaeoecol. 166, 319-329 (2001).

68. Vella, C. et al. Evolution of the Rhône delta plain in the Holocene. Mar. Geol. 222, 235-265 (2005).

69. Allinne et al. Archéologie et paléoenvironnement sur le site du pont romain des Esclapes (Fréjus, Var). ArcheoSciences. Rev. d'archéom.étrie 30, 181-196 (2006).

70. Devillers, B., Excoffon, P., Morhange, C., Bonnet, S. \& Bertoncello, F. Relative sea-level changes and coastal evolution at Forum Julii (Fréjus, Provence). Comptes Rendus Geosci. 339, 329-336 (2007).

71. Morhange, C. et al. Relative sea-level changes during Roman times in the northwest Mediterranean: the 1st century AD fish tank of Forum Julii, Fréjus, France. Geoarchaeology 28, 363-372 (2013).

72. Colombaroli, D., Marchetto, A. \& Tinner, W. Long-term interactions between Mediterranean climate, vegetation and fire regime at Lago di Massaciuccoli (Tuscany, Italy). J. Ecol. 95, 755-770 (2007).

73. Carboni, M. G. et al. Palaeoenvironmental reconstruction of late Quaternary foraminifera and molluscs from the ENEA borehole (Versilian plain, Tuscany, Italy). Quat. Res. 74, 265-276 (2010). 
74. Kaniewski, D. et al. Holocene evolution of Portus Pisanus, the lost harbour of Pisa. Sci. Rep. 8, 11625 (2018).

75. Ghilardi, M. et al. Reconstructing the landscape evolution and the human occupation of the Lower Sagone River (Western Corsica, France) from the Bronze Age to the Medieval period. J. Archaeological Sci.: Rep. 12, 741-754 (2017).

76. Ghilardi, M. et al. Enregistrements d'événements extrêmes et évolution des paysages dans les basses vallées fluviales du Taravo et du Sagone (Corse occidentale, France) au cours de l'âge du Bronze moyen à final: une perspective géoarchéologique. Geomorphol. Relief, Process. Environ. 23, 15-35 (2017).

77. Vacchi, M., Ghilardi, M., Spada, G., Currás, A. \& Robresco, S. New insights into the sea-level evolution in Corsica (NW Mediterranean) since the late Neolithic. J. Archaeological Sci.: Rep. 12, 782-793 (2017).

78. Poher, Y., Ponel, P., Médail, F., Andrieu-Ponel, V. \& Guiter, F. Holocene environmental history of a small Mediterranean island in response to sea-level changes, climate and human impact. Palaeogeogr., Palaeoclimatol., Palaeoecol. 465, 247-263 (2017).

79. Lambeck, K., Anzidei, M., Antonioli, F., Benini, A. \& Verrubbi, V. Tyrrhenian sea level at 2000 BP: evidence from Roman age fish tanks and their geological calibration. Rendiconti Lincei. Sci. Fisiche e Nat. 29, 69-80 (2018).

80. Lambeck, K., Anzidei, M., Antonioli, F., Benini, A. \& Esposito, A. Sea level in Roman time in the Central Mediterranean and implications for recent change. Earth Planet. Sci. Lett. 224, 563-575 (2004).

81. Evelpidou, N. et al. Late Holocene sea level reconstructions based on observations of Roman fish tanks, Tyrrhenian Coast of Italy. Geoarchaeology 27, 259-277 (2012).

82. Marra, F., Bozzano, F. \& Cinti, F. R. Chronostratigraphic and lithologic features of the Tiber River sediments (Rome, Italy): implications on the postglacial sea-level rise and Holocene climate. Glob. Planet. Change 107, 157-176 (2013).

83. Salomon, F. Géoarchéologie du delta du Tibre: évolution géomorphologique holocène et contraintes hydrosédimentaires dans le système Ostie-Portus (Italie). Thèse de doctorat en géographie, option géoarchéologie. Physio-Géo. Géographie Phys. et. Environ. 8, 1-6 (2014).

84. Goiran, J. P., Tronchère, H., Collalelli, U., Salomon, F. \& Djerbi, H. Découverte d'un niveau marin biologique sur les quais de Portus: le port antique de Rome. Méditerranée 112, 59-67 (2009).

85. De Muro, S. \& Orrù, P. Il contributo delle Beach-Rock nello studio della risalita del mare olocenico. Le Beach-Rock post-glaciali della Sardegna nordorientale. Il Quaternario 111, 19-39 (1998).

86. Melis, R. T. et al. 8000 years of coastal changes on a western Mediterranean island: a multiproxy approach from the Posada plain of Sardinia. Mar. Geol. 403, 93-108 (2018).

87. Melis, R. T., Depalmas, A., Di Rita, F., Montis, F. \& Vacchi, M. Mid to late Holocene environmental changes along the coast of western Sardinia (Mediterranean Sea). Glob. Planet. Change 155, 29-41 (2017).

88. Di Rita, F. \& Melis, R. T. The cultural landscape near the ancient city of Tharros (central West Sardinia): vegetation changes and human impact. J. Archaeological Sci. 40, 4271-4282 (2013).

89. De Falco, G. et al. Early cementation and accommodation space dictate the evolution of an overstepping barrier system during the Holocene. Mar. Geol. 369, 52-66 (2015).

90. Ruiz, J. M., Carmona, P., Gómez-Bellard, C. \& van Dommelen, P. Geomorfología y cambio ambiental en el entorno de los yacimientos púnicos de la llanura de Terralba (Golfo de Oristano, isla de Cerdeña, Italia). Boletín Geol.ógico y. Min. 129, 331-352 (2018).

91. Orrù, P., Solinas, E., Puliga, G. \& Deiana, G. Palaeo-shorelines of the historic period. Sant'Antioco Island, south-western Sardinia (Italy). Quat. Int. 232, 71-81 (2011)

92. Orrù, P. E. et al. Sea level changes and geoarchaeology between the bay of Capo Malfatano and Piscinnì Bay (SW Sardinia) in the last 4 kys. Quat. Int. 336, 180-189 (2014)

93. Orrù, P. E., Antonioli, F., Lambeck, K. \& Verrubbi, V. Holocene sea-level change in the Cagliari coastal plain (southern Sardinia, Italy). Quaternaria Nova 8, 193-212 (2004).

94. Barra, D. et al. The Versilian transgression in the Volturno river plain (Campania, Southern Italy): Palaeoenvironmental history and chronological data. Il Quaternario 9, 445-458 (1996).

95. Sacchi, M. et al. Late-Holocene to recent evolution of Lake Patria, South Italy: an example of a coastal lagoon within a Mediterranean delta system. Glob. Planet. Change 117, 9-27 (2014).

96. Barra, D. et al. Depositional history and palaeogeographic reconstruction of Sele coastal plain during Magna Grecia settlement of Hera Argiva (Southern Italy). Geologica Romana 35, 151-166 (1999).

97. Amato, V. et al. Relative sea level changes and paleogeographical evolution of the southern Sele plain (Italy) during the Holocene. Quat. Int. 288, 112-128 (2013).
98. Barra, D. et al. New data on the evolution of the Sele River coastal plain (southern Italy) during the Holocene. Il Quaternario 11, 287-299 (1998).

99. Antonioli, F., Chemello, R., Improta, S. \& Riggio, S. The Dendropoma (Mollusca Gastropoda, Vermetidae) intertidal reef formations and their paleoclimatological use. Mar. Geol. 161, 155-170 (1999).

100. Basso, D., Bernasconi, M. P., Robba, E. \& Marozzo, S. Environmental evolution of the Marsala sound, Sicily, during the last 6000 years. J. Coast. Res. 24, 177-197 (2008).

101. Spampinato, C. R., Costa, B., Di Stefano, A., Monaco, C. \& Scicchitano, G. The contribution of tectonics to relative sea-level change during the Holocene in coastal south-eastern Sicily: new data from boreholes. Quat. Int. 232, 214-227 (2011).

102. Gerardi, F. et al. Geological record of tsunami inundations in Pantano Morghella (south-eastern Sicily) both from near and far-field sources. Nat. Hazards Earth Syst. Sci. 12, 1185-1200 (2012).

103. Marriner, N., Gambin, T., Djamali, M., Morhange, C. \& Spiteri, M. Geoarchaeology of the Burmarrad ria and early Holocene human impacts in western Malta. Palaeogeogr., Palaeoclimatol., Palaeoecol. 339, 52-65 (2012).

104. Furlani, S. et al. Submerged speleothem in Malta indicates tectonic stability throughout the Holocene. Holocene 28, 1588-1597 (2018).

105. Zaîbi, C. et al. Évolution du trait de côte à l'Holocène supérieur dans la Sebkha El-Guettiate de Skhira (Golfe de Gabès, Tunisie) à travers sa faune d'ostracodes et de foraminifères. Geobios 44, 101-115 (2011).

106. Zaïbi, C. et al. Evolution of the sebkha Dreîaa (South-Eastern Tunisia, Gulf of Gabes) during the Late Holocene: response of ostracod assemblages. Rev. de. micropaléontologie 55, 83-97 (2012).

107. Morhange, C. \& Pirazzoli, P. A. Mid-Holocene emergence of southern Tunisian coasts. Mar. Geol. 220, 205-213 (2005).

108. Strasser, A., Davaud, E. \& Jedoui, Y. Carbonate cements in Holocene beachrock: example from Bahiret et Biban, southeastern Tunisia. Sediment. Geol. 62, 89-100 (1989).

109. Lakhdar, R., Soussi, M., Ben Ismail, M. H. \& M'Rabet, A. A Mediterranean Holocene restricted coastal lagoon under arid climate: case of the sedimentary record of Sabkha Boujmel (SE Tunisia). Palaeogeogr., Palaeoclimatol., Palaeoecol. 241, 177-191 (2006).

110. Serandrei-Barbero, R., Albani, A., Donnici, S. \& Rizzetto, F. Past and recent sedimentation rates in the Lagoon of Venice (Northern Italy). Estuar., Coast. Shelf Sci. 69, 255-269 (2006).

111. McClennen, C. E. \& Housley, R. A. Late-Holocene channel meander migration and mudflat accumulation rates, lagoon of Venice, Italy. J. Coast. Res. 224, 930-945 (2006).

112. Zoppi, U. et al. Preliminary estimate of the reservoir age in the Lagoon of Venice. Radiocarbon 43, 489-494 (2001).

113. Madricardo, F. \& Donnici, S. Mapping past and recent landscape modifications in the Lagoon of Venice through geophysical surveys and historical maps. Anthropocene 6, 86-96 (2014).

114. Tosi, L. Foglio geologico 128 Venezia e note illustrative. Carta geologica d'Italia alla scala 1, 000 (2007).

115. Donnici, S., Serandrei-Barbero, R. \& Canali, G. Evidence of climatic changes in the Venetian Coastal Plain (Northern Italy) during the last 40,000 years. Sediment. Geol. 281, 139-150 (2012).

116. Galassi, P. \& Marocco, R. Relative sea level rise and subsidence in the Caorle Lagoon (Northern Adriatic Sea), Italy, during Holocene. Il Quaternario 12, 249-256 (1999)

117. Fontana, A. et al. Lagoonal settlements and relative sea level during Bronze age in Northern Adriatic: geoarchaeological evidence and paleogeographic constraints. Quat. Int. 439, 17-36 (2017).

118. Fontana, A. \& Zanferrari. A. Foglio geologico 86 San Vito al Tagliamento e note illustrative. Carta geologica d'Italia alla scala 1:50,000 (2006).

119. Bondesan, A., Meneghel, M., Rosselli, R. \& Vitturi. A. Geomorphological Map of the Province of Venice, scale 1:50,000 (LAC, Firenze, 2004).

120. Furlani, S. et al. Tectonic effects on Late Holocene sea level changes in the Gulf of Trieste (NE Adriatic Sea, Italy). Quat. Int. 232, 144-157 (2011).

121. Covelli, S., Fontolan, G., Faganeli, J. \& Ogrinc, N. Anthropogenic markers in the Holocene stratigraphic sequence of the Gulf of Trieste (northern Adriatic Sea). Mar. Geol. 230, 29-51 (2006).

122. Melis, R. et al. Sea level and paleoenvironment during roman times inferred from coastal archaeological sites in Trieste (northern Italy). Alp. Mediterranean Quat. 25, 41-55 (2012).

123. Ogorelec, B., Faganeli, J., Mišič, M. \& Čermelj, B. Reconstruction of paleoenvironment in the Bay of Koper (Gulf of Trieste, northern Adriatic). Annales 11, e200 (1997).

124. Faivre, S. et al. Relative sea level change in western Istria (Croatia) during the last millennium. Quat. Int. 232, 132-143 (2011).

125. Cibin, U. \& Stefani, M. Foglio geologico 187 Codigoro e note illustrative. Carta geologica d'Italia alla scala 1:50,000 (2009).

126. Correggiari, A., Roveri, M. \& Trincardi, F. Late Pleistocene and Holocene evolution of the north Adriatic Sea. Il Quaternario 9, 697-704 (1996). 
127. Sarti, G., Centineo, M. C. \& Calabrese, L. Foglio geologico 205 Comacchio e note illustrative. Carta geologica d'Italia alla scala 1:50,000 (2009).

128. Marriner, N. et al. Post-Roman sea-level changes on Pag Island (Adriatic Sea): dating Croatia's "enigmatic" coastal notch? Geomorphology 221, 83-94 (2014).

129. Faivre, S., Bakran-Petricioli, T., Horvatinčić, N. \& Sironić, A. Distinct phases of relative sea level changes in the central Adriatic during the last 1500 yearsinfluence of climatic variations? Palaeogeogr. Palaeoclimatol. Palaeoecol. 369, 163-174 (2013).

130. Caldara, M., Caroli, I. \& Simone, O. Holocene evolution and sea-level changes in the Battaglia basin area (eastern Gargano coast, Apulia, Italy). Quat. Int. 183, 102-114 (2008)

131. Caldara, M. \& Simone, O. Coastal changes in the eastern Tavoliere Plain (Apulia, Italy) during the Late Holocene: natural or anthropic? Quat. Sci. Rev. 24, 2137-2145 (2005).

132. Di Rita, F., Simone, O., Caldara, M., Gehrels, W. R. \& Magri, D. Holocene environmental changes in the coastal Tavoliere Plain (Apulia, southern Italy): a multiproxy approach. Palaeogeogr., Palaeoclimatol., Palaeoecol. 310, 139-151 (2011).

133. Primavera, M., Simone, O., Fiorentino, G. \& Caldara, M. The palaeoenvironmental study of the Alimini Piccolo lake enables a reconstruction of Holocene sea-level changes in southeast Italy. Holocene 21, 553-563 (2011).

134. Morhange, C. \& Marriner, N. Handbook of Sea-level Research Ch. 9 (John Wiley and Sons, 2015).

135. Scicchitano, G. et al. Uplifted Holocene shorelines at Capo Milazzo (NE Sicily, Italy): evidence of co-seismic and steady-state deformation. Quat. Int. 232, 201-213 (2011).

136. Aucelli, P. P., Cinque, A., Mattei, G. \& Pappone, G. Late Holocene landscape evolution of the gulf of Naples (Italy) inferred from geoarchaeological data. $J$. Maps 13, 300-310 (2017).

137. Shennan, I. \& Horton, B. Holocene land-and sea-level changes in Great Britain. J. Quat. Sci. 17, 511-526 (2002).

138. McHutchon, A. \& Rasmussen, C. Gaussian process training with input noise. Adv. Neural Inf. Process. Syst. 24, 1341-1349 (2011).

\section{Acknowledgements}

M.V. is funded by the Rita Levi Montalcini program of the Italian Ministry of University and Research (MUR). A.R. thanks the Deutsche Forschungsgemeinschaft (Excellence Cluster "EXC 2077: The Ocean Floor-Earth's Uncharted Interface", project no. 390741603) for support. R.E.K. and K.J. were supported by US National Science Foundation grants DGE-1633557 and OCE-1804999. We further acknowledge PALSEA, a working group of the International Union for Quaternary Sciences (INQUA) and Past
Global Changes (PAGES), which in turn received support from the Swiss Academy of Sciences and the Chinese Academy of Sciences.

\section{Author contributions}

M.V., K.J., R.E.K., and A.R. designed the research approach. M.V. led the research and wrote the first draft of the paper. M.V., N.M., D.K., and A.R. contributed to compiling the sea-level database. K.J. and R.E.K. performed the statistical analysis. M.V., K.J., R.E K., N.M., D.K., and A.R. contributed to the writing of the manuscript.

\section{Competing interests}

The authors declare no competing interests.

\section{Additional information}

Supplementary information The online version contains supplementary material available at https://doi.org/10.1038/s41467-021-24250-1.

Correspondence and requests for materials should be addressed to M.V.

Peer review information Nature Communications thanks Marco Anzidei and the other, anonymous, reviewer(s) for their contribution to the peer review of this work.

Reprints and permission information is available at http://www.nature.com/reprints

Publisher's note Springer Nature remains neutral with regard to jurisdictional claims in published maps and institutional affiliations.

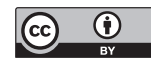

Open Access This article is licensed under a Creative Commons Attribution 4.0 International License, which permits use, sharing, adaptation, distribution and reproduction in any medium or format, as long as you give appropriate credit to the original author(s) and the source, provide a link to the Creative Commons license, and indicate if changes were made. The images or other third party material in this article are included in the article's Creative Commons license, unless indicated otherwise in a credit line to the material. If material is not included in the article's Creative Commons license and your intended use is not permitted by statutory regulation or exceeds the permitted use, you will need to obtain permission directly from the copyright holder. To view a copy of this license, visit http://creativecommons.org/ licenses/by/4.0/.

(C) The Author(s) 2021 